\title{
BUILDING COALITIONS: Introduction
}

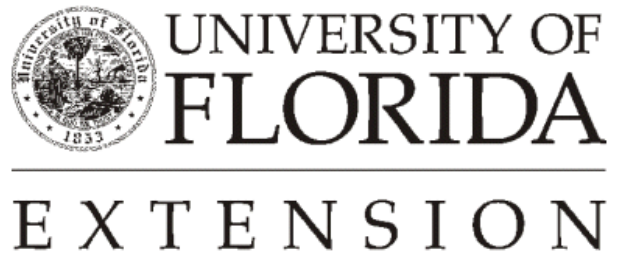

Institute of $\mathbf{F}_{\text {ood and }} \mathbf{A}_{\text {gricultural }} \mathbf{S}_{\text {ciences }}$ 
This is the first in a series of fact sheets compiled by The Ohio Center for Action on Coalitions and lays the groundwork for future fact sheets.

\section{Advantages and Disadvantages}

Collaboration with other youth-serving organizations can be an effective and rewarding method of teaching young people. But, collaborating with other groups is a double-edged sword with both advantages and disadvantages. Both should be weighed before entering a collaborative effort. If the benefits don't outweigh the costs, collaboration should not take place.

The advantages of entering a collaborative effort may be immediate or long term, direct or indirect. Some partners may benefit more than others. It is essential that each partner recognize that the benefits will outweigh the costs of participation. (Dluhy 1990)

\section{Advantages}

The advantages of collaborating most frequently are: more effective and efficient delivery of programs, professional development, improved communication, elimination of duplication, increased use of programs, improved public image, better needs assessment, consistency of information and increased availability of resources.

Collaboration can open a vast complement of resources to the innovative administrator-new staff skills, knowledge, equipment and facilities, and services. These may be available at other agencies.

Combining the resources of two or more agencies can help deliver more services for the same money or the same services for less money. The economics of scale, fewer duplicate programs and improved cost-benefit ratios will make the delivery of the program more effective and efficient. (Rossi 1982)

Staff members will grow professionally by meeting with colleagues from other agencies. They will be exposed to new methods and ideas that may benefit them. They may be made aware of new resources that are available and how to obtain them for their programs.

Improved communication between agencies will result in all partners providing more consistent and reliable information to the client. Shared information can mean increased use of programs and more public support. Agencies can share information about policy and legislative issues that effect their clientele groups. A better understanding of work done by others may help when directing clients who need critical information. Better communication between agencies will provide a better evaluation of the total impact of programs.

Coordinated needs assessment can be a benefit of collaboration. Service providers who work together can identify gaps in programs. They also can see critical widespread problems and rate issues for the most efficient use of available resources. 


\section{Disadvantages}

Some disadvantages of collaborations are: turf protection and mistrust, slow decision-making, limited resources, diverted resources from priority issues, an assumed position contrary to policy and decreased level of cooperation among collaborators during a crisis.

Turf protection and mistrust are complex issues that must be overcome. If a collaborator doesn't trust his or her partners, he or she will not be as open and receptive to new ideas. There will not be a willingness to share resources and burdens.

If a group must reach a consensus to act on an issue, it may take time. Many partners may not be able to go forward without approval of a higher authority or more study. Depending on how well the group communicates or how often it meets, decision by consensus could make acting on a problem slow and ineffective.

Due to limitations of resources, some groups who would be valuable partners are unable to cooperate. Devoting resources to a collaborative effort may take away from other high priority projects.

Sometimes a coalition may take a position that is inconsistent with the policy of one of its partners. This may cause the partner to be uncooperative, ineffective or to withdraw from the coalition. During a crisis with a partner or the coalition, cooperation among members may decrease. Member organizations are sometimes faced with changes within their organization such as budget cuts, changes in administration or other short-term changes that will affect their commitment.

Withdrawal of support by a key member or outside pressures from individuals or groups who disagree with or don't understand the coalition's purpose may cause a crisis. This may strain the partnership. 


\section{Definitions}

- $\quad$ Alliance - Individuals or organizations working together in a common effort for a common purpose to make effective and efficient use of resources; a coalition.

- Coalition - Individuals or organizations working together in a common effort for a common purpose to make effective and efficient use of resources; an alliance.

Collaboration - Individuals or organizations associating to accomplish a common goal.

Coordination - Individuals or organizations associating to accomplish a common goal.
- $\quad$ Network - Individuals or organizations who share information, ideas, resources, or services to accomplish individual or group goals.

- $\quad$ Partner - An individual or organization working with others to accomplish a common goal with a shared sense of purpose and sharing responsibility for the outcome.

- Partnership - Individuals or organizations working together in a side-by-side effort to accomplish a common goal with a shared responsibility for the outcome.

\section{Summary}

This fact sheet provides an understanding of the terms and some reasons for building coalitions. It is intended to help individuals to better use the series of fact sheets developed by the Ohio Center for Action on Coalitions. Comments and ideas for improvement are welcomed. 


\section{References}

Black, Terry R. "Coalition Building-Some Suggestions." Child Welfare (May-June 1983).

Dluhy, Milan J. Building Coalitions in the Human Services. Newbury Park, California: Sage Publications, 1990.

Etling, Arlene. "Multiplying Partnerships." Journal of Extension (Fall 1986).

McLendon, Ellawese B. "Networking Opens Doors." Journal of Extension (Spring 1988). "Partnerships for the Future." Conference Proceedings, Department of Social and Health Services. Washington State, April 1987.

Rossi, Robert J., et al. Agencies Working Together, A Guide to Coordinating and Planning. Beverly Hills, California: Sage Publications, 1982.

Wisconsin State Department of Public Instruction. Planning for State Solutions to the Problems of Youth at Risk, Final Report, Fall 1988. Bulletin No. 9244. Madison, Wisconsin: Wisconsin State Department of Public Instruction, January 1989.

\section{Authors}

Daney Jackson, Graduate Associate, The Ohio Center For Action on Coalition Development, Ohio Cooperative Extension Service, The Ohio State University.

William Maddy, Administrative Assistant, The Ohio Center For Action on Coalition Development, Ohio Cooperative Extension Service, The Ohio State University.

\section{(C) 1992 The Ohio State University}

This series on Coalition Building was developed by The Ohio Center For Action on Coalition Development for Family and High Risk Youth, Richard Clark, Ph.D., Director. It has been adapted for County Extension Faculty in Florida to facilitate work with local and regional organizations and groups such as non-profits, cooperatives, county extension associations, and others that might benefit from a plan for working together to achieve support for mutual goals.

This document is FY493, Part 1 of the 16 part series adapted for use in Florida by Elizabeth B. Bolton, Professor, Community Development and Lisa Guion, Assistant Professor, Program Planning and Evaluation; Department of Family, Youth and Community Sciences, Florida Cooperative Extension Service, Institute of Food and Agricultural Sciences, University of Florida, Gainesville, 326110310 .

Reprinted with permission March, 1997. Revised April, 2002.

The Institute of Food and Agricultural Sciences is an equal opportunity/affirmative action employer authorized to provide research, educational information and other services only to individuals and institutions that function without regard to race, color, sex, age, handicap, or national origin. For information on obtaining other extension publications, contact your county Cooperative Extension Service office.

Florida Cooperative Extension Service/Institute of Food and Agricultural Sciences/University of Florida/Christine Taylor Waddill, Dean 